\title{
Hubungan Tingkat Konsumsi Protein, Vitamin C, Zat Besi dan Asam Folat dengan Kejadian Anemia Pada Remaja Putri SMAN 4 Surabaya
}

\section{Correlation between Consumption Level of Protein, Vitamin C, Iron and Folic Acid with Anemia among Female Teenagers at SMAN 4 Surabaya}

\author{
Ni'matush Sholihah*1, Sri Andari², Bambang Wirjatmadi $^{3}$
}

\begin{abstract}
ABSTRAK
Latar Belakang: Prevalensi anemia pada remaja putri cukup tinggi dan hal tersebut dipengaruhi oleh beberapa faktor, diantaranya asupan zat besi yang rendah dan didukung oleh absorbsi yang rendah pula, pendarahan, penyakit malaria, infeksi cacing maupun infeksi lainnya, selain itu wanita juga mengalami menstruasi setiap bulannya.

Tujuan: Penelitian ini bertujuan untuk menganalisis hubungan tingkat konsumsi protein, vitamin c, zat besi dan asam folat dengan status anemia pada remaja putri.

Metode: Penelitian ini menggunakan rancangan case control dengan sampel kelas X di SMAN 4 Surabaya. Besar sampel dari penelitian ini yaitu 44 responden, yang terdiri dari 22 kelompok kontrol (kelompok yang tidak anemia) dan 22 responden kasus (kelompok yang anemia). Sebelumnya dilakukan pengambilan data awal untuk mengetahui jumlah populasi yang anemia, dan didapatkan sebanyak 36 orang terindikasi anemia. Data asupan protein, vitamin $C$, zat besi dan asam folat didapatkan melalui metode recall 2 × 24 hours lalu dibandingkan dengan AKG. Kadar hemoglobin diukur dengan alat easy touch. Uji statistik yang dilakukan yaitu uji korelasi pearson

Hasil: Setelah dilakukan penelitian, didapatkan hasil yaitu terdapat hubungan yang signifikan antara kejadian anemia dengan tingkat konsumsi protein $(p<0,001 ; O R=30,33)$, kejadian anemia dengan tingkat konsumsi zat besi $(p<0,001$; $O R=8,737)$ dan yang terakhir hubungan antara kejadian anemia dengan tingkat konsumsi asam folat $(p=0,01 ; O R=9,067)$. Sebaliknya, tidak ditemukan hubungan yang signifikan antara tingkat konsumsi vitamin $C$ dengan kejadian anemia $(p=1,0)$. Kesimpulan: Dari hasil penelitian ini dapat disimpulkan bahwa terdapat hubungan yang signifikan antara tingkat konsumsi protein, zat besi dan asam folat, dan tidak terdapat hubungan yang signifikan antara tingkat konsumsi vitamin c dengan anemia. Remaja putri disarankan untuk meningkatkan konsumsi makanan yang kaya akan protein, zat besi dan asam folat seperti sayur-sayuran dan buah-buahan.
\end{abstract}

Kata Kunci: Anemia, tingkat konsumsi, remaja putri.

\section{ABSTRACT}

Background: The prevalence of anemia in adolescent girls was quite high and this is influenced by several factors, including low iron intake, low iron absorption, bleeding, malaria, worm infections and other infections, and also menstruation every month.

Objective: The purpose of this research was to analyze the relationship between the level of protein, vitamin $C$, iron and folic acid with anemia among female teenagers.

Method: This research a was case control design on class $X$ at SMAN 4 Surabaya. The subject was 44 teenagers, consisting of 22 girls in the control groups and 22 girls in the case groups. Preliminary screening prior to the research found 36 people indicated anemia. Intake of protein, vitamin C, iron and folic acid were obtained through dietary food recall method $2 \times 24$ hours and compared to the Indonesian standard (AKG). Hemoglobin level was measured using the EasyTouch heamoglobin meter device. The statistical test used in the study was Pearson Correlation test.

Result: The results showed that there was significant relationship between the level of protein consumption and incidence of anemia ( $p<0.001)$; iron consumption level and anemia $(p=0.01)$ and level of folic acid intake and anemia $(p<0.001)$. On the other hand, there was no significant relationship found between consumption level of vitamin $C$ and anemia $(p=1.0)$.

Conclusion: There was significant correlation between level consumption of protein, iron, folid acid and the incidence of anemia, and no significant relationship was found between consumption level of vitamin $C$ and anemia. 
Keywords: anemia, level of consumption, girls, teenager

\author{
*Koresponden: \\ nimahdhanis29@gmail.com \\ 1,3Prodi S-1 Gizi , Fakultas Kesehatan Masyarakat Universitas Airlangga, Kampus C Mulyorejo, 60115, Surabaya, Indonesia \\ 2Dinas Kesehatan Sidoarjo, Jl. Mayjend Sungkono No.46, Pucang, Kec. Sidoarjo, 61252, Kab.Sidoarjo, Jawa Timur, Indonesia
}

\section{PENDAHULUAN}

Sebagai salah satu negara berkembang, Indonesia masih memiliki beberapa hal yang tertinggal dibandingkan dengan negara maju, salah satunya dibidang kesehatan. Salah satu masalah kesehatan yang perlu untuk diperhatikan adalah masalah gizi. Di Indonesia sendiri, terdapat 5 masalah gizi yang menjadi sorotan hingga saat ini, slah satunya adalah anemia. Diperkirakan lebih dari 1,5 milyar atau $30 \%$ peduduk yang ada didunia menderita anemia dan sebagian besar adalah penduduk yang tinggal didaerah tropis ${ }^{1}$.

Pada tahun 2015 lebih dari dua milyar orang di dunia berstatus anemia, dan negara berkembang mendominasi prevalensi kejadian anemia tersebut, salah satunya Indonesia². Berdasarkan hasil Riskesdas 2018, diketahui bahwa terjadi peningkatan anemia di Indonesia pada 2018 yaitu sebesar 48.9\%, dengan prevalensi terbesar pada ibu hamil berusia 15-24 tahun yaitu sebanyak $84.6 \%{ }^{3}$.

Prevalensi anemia pada remaja putri cukup tinggi dan hal tersebut dipengaruhi oleh beberapa faktor, diantaranya asupan zat besi yang rendah dan didukung oleh absorbsi yang rendah pula, pendarahan, penyakit malaria, infeksi cacing maupun infeksi lainnya, selain itu remaja putri setiap bulannya mendapatkan datang bulan (haid) ${ }^{4}$. Pada remaja putri banyak yang menganggap bahwa kurus itu cantik, sehingga melakukan diet ketat merupakan salah satu pilihan dengan cara mengurangi konsumsi makanan dan dapat menyebabkan kurang beragamnya makanan yang dikonsumsi sehingga berdampak pada kurangnya berbagai zat gizi yang dibutuhkan oleh tubuh termasuk zat besi ${ }^{5}$.

Anemia zat gizi(besi) merupakan salah satu anemia yang paling sering terjadi. Tingginya prevalensi anemia zat besi umumnya disebabkan asupan makanan yang lebih rendah dari yang dianjurkan, terutama kurangnya asupan makanan yang mengandung zat besi 6. Pengangkutan (transportasi) oleh protein dan penyerapan zat besi oleh vitamin c dalam tubuh akan mempengaruhi kadar zat besi yang tersedia di dalam tubuh.. Selain itu, pengetahuan zat gizi remaja dapat mempengaruhi jumlah dan jenis makanan yang masuk kedalam tubuh. Akibat dari kurangnya pengetahuan tentang zat gizi, makanan yang dikonsumsi seringkali tidak mencukupi kebutuhan gizi remaja putri ${ }^{4}$. Berdasarkan penelitian yang dilakukan di SMKN 1 Manggis, diketahui bahwa terdapat hubungan yang signifkan antara pola konsumsi baik dari segi jenis, jumlah maupun frekuensi konsumsi protein, zat besi, dan vitamin $C$ dengan kejadian anemia pada remaja putri?.
Sudah terdapat banyak penelitian anemia yang dilakukan di SMA maupun SMP di Surabaya. Berdasarkan penetian yang dilakukan di SMAN 3 didapatkan sebanyak $51,79 \%$ responden mengalami anemia. Jumlah responden dalam penelitian tersebut adalah 56 orang, dengan hasil 29 orang $(51,79 \%)$ mengalami anemia dan sebanyak 27 orang $(48,21 \%)$ tidak mengalami anemia. Hal ini menunjukkan bahwa lebih dari setengah responden yang diambil mengalami anemia ${ }^{8}$. Selain itu, penelitian yang dilakukan oleh Rabbani (2018) di SMPN 55 menunjukkan bahwa sebanyak 32\% dari sampel mengalami anemia ${ }^{9}$

SMAN 4 Surabaya adalah salah satu SMA di Surabaya yang letaknya cukup strategis. SMA ini terletak di jalan Prof. Dr. Moestopo 4, Surabaya. SMA ini terdiri dari kelas $X$ hingga XII dengan 2 program/peminatan yaitu IPA dan IPS. Pada SMAN 4 ini pernah dilakukan penelitian terkait anemia pada tahun 2010, penelitian tersebut menunjukkan bahwa sebanyak $15,7 \%$ remaja putri mengalami anemia. Selain itu, diketahui pula, sebesar $41,67 \%$ remaja putri yang mengalami anemia defisit asupan protein, lalu sebanyak $83,3 \%$ mengalami defisit vitamin C, 75\% remaja putri mengalami defisit asam folat, dan $100 \%$ remaja putri yang anemia mengalami defisit zat besi ${ }^{10}$.

Penelitian ini bertujuan untuk menganalisis hubungan tingkat konsumsi protein, vitamin C, zat besi dan asam folat dengan kejadian anemia pada remaja putri di SMAN 4 Surabaya.

\section{METODE}

Jenis penelitian ini bersifat observasional karena tidak melakukan intervensi atau perlakuan apapun terhadap sampel penelitian dan menggunakan design penelitian case control study atau studi kasus kontrol. Pengambilan data pada penelitian ini dilakukan pada bulan April 2019.

Populasi penelitian ini adalah remaja putri kelas $X$ di SMAN 4 Surabaya, dengan jumlah populasi sebanyak 142 orang, pengambilan kelas $X$ saja sebagai populasi dikarenakan faktor perizinan dan juga untuk mempermudah skrining awal pada peneltian ini. Skrining awal ini dilakukan untuk klasifikasi kelompok kasus (kelompok yanga anemia) dan kelompok kontrol (kelompok yang tidak anemia). Skrining awal pada penelitian ini dilakukan dengan pengukuran kadar $\mathrm{Hb}$ pada seluruh populasi, setelah itu populasi dikategorikan menjadi kelompok kasus dan kontol. Pengambilan sampel dilakukan dengan simple random sampling pada masingmasing kelompok. Perhitungan sampel dilakukan dengan rumus Kuntoro dan didapatkan jumlah sampel 
minimal sebanyak 44 orang, yang terdiri dari 22 kelompok kontrol dan 22 kelompok kasus ${ }^{11}$.

Penelitian ini mengumpulkan data primer dan sekunder. Penelitian ini menggunakan design penelitian case control, yaitu penelitian dilakukan dengan mengidentifikasi outcome terlebih dahulu, lalu memperhatikan salah satu factor penyebab yaitu asupan respoden, maka dari itu data primer yang diambil pertama adalah kadar $\mathrm{Hb}$ yang diambil dengan alat easytouch pada saat skrining awal dan pemeriksaan dilakukan oleh tenaga perawat yang sudah terlatih, setelah pengkategorian kelompok kasus dan kelompok kontrol sesuai jumlah sampel, dilakukan wawancara dengan responden untuk mengetahui karakteristik orang tua (pekerjaan dan pendapatan), karakteristik remaja putri (usia dan pengetahuan) dengan menggunakan kuisioner, pengetahuan remaja dilkasifikasikan menjadi tinggi (skor $>80$ ), sedang (skor 60-80) dan rendah (skor $<60)^{12}$, setelah itu dilakukan wawancara terkait tingkat konsumsi yang diukur dengan food recall 2x24 jam dengan hari yang tidak berurutan (weekend dan weekdays). Hasil food recall $2 \times 24$ jam yang didapat diolah menggunakan nutrisurvey sehingga didapatkan asupan protein, zat besi, vitamin $C$ dan asam folat. Hasil tersebut kemudian dibandingkan denga AKG (Angka Kecukupan Gizi) dengan klasifikasi cukup jika $\geq 77 \%$ dan kurang jika $<77 \%$ dari AKG $^{13}$ untuk zat besi, vitamin C dan asam folat, sedangkan untuk prtotein diklasifikasikan menjadi cukup jika asupan $\geq 80 \%$ dan kurang jika $<80 \%$ dari AKG ${ }^{14}$.

Analisis deskriptif dilakukan untuk mengetahui distribusi frekuensi dan persentase dari setiap variabel, yaitu, tingkat konsumsi (protein, vitamin c, zat besi dan asam folat), karakteristik responden dan karakteristik orang tua. Analisis inferensial digunakan dengan menggunakan analisis bivariat untuk melihat hubungan antara variabel independen dengan variabel dependen. Pada penelitian ini untuk melihat hubungan antara antara tingkat konsumsi (Protein, Vitamin C, fe dan asam folat) dengan status anemia dilakukan uji normalitas terlebih dahulu dan didapatkan hasil distribusi normal, sehingga digunakan uji korelasi pearson untuk mengetahui hubungan antar variabel.

Penelitian ini telah lulus Komisi Etik Penelitian Fakultas Kesehatan Masyarakat dengan nomor sertifikat 110/EA/KEPK/2019.

\section{HASIL DAN PEMBAHASAN}

\section{Karakteristik Orang Tua}

Pekerjaan orang tua yang ditanyakan melalui kuisioner karakteristik remaja. Pekerjaan yang ditanyakan terdiri dari pekerjaan ibu dan ayah. Distribusi karakteristik responden dan orang tua responden tersaji dalam tabel 1.

Berdasarkan tabel distribusi karakteristik responden dan orang tua responden, diketahui bahwa sebagian besar ayah responden baik dari kelompok kasus maupun kontrol merupakan pegawai swasta. Dari kelompok kasus (kelompok yang anemia), terdapat 12 ayah $(54,6 \%)$ yang bekerja sebagai pegawai swasta, dan pada kelompok kontrol sebanyak 9 ayah $(40,9 \%)$ bekerja sebagai pegawai swasta. Selanjutnya, pada pekerjaan ibu, sebagian besar bekerja sebagai ibu rumah tangga, dari kelompok kasus sebanyak 10 orang $(45,5 \%)$ dan dari kelompok kontrol sebanyak 10 orang $(63,6 \%)$.

Pendapatan responden diambil dari total pendapatan ayah dan ibu, untuk total pendapatan sebagian besar berada pada quartil 1 dengan rentang 1.5000.000-9. 000.000, pada kelompok kasus sebanyak 17 orang dan pada kelompok kontrol sebanyak 18 orang.

Pada umumnya, keluarga dengan profesi yang stabil, akan memiliki tingkat pendapatan yang lebih tinggi jika dibandingkan dengan profesi pekerjaan yang tidak stabil. Selain itu, pekerjaan orang tua juga dapat mempengaruhi pengetahuan dari orang tua responden, dimana hal tersebut dapat dipengaruhi oleh teman kerja orang tua yang dapat menjadi sumber informasi. Dari pengetahuan ini, dapat mempengaruhi penyediaan bahan makanan maupun makanan yang disajikan untuk dikonsumsi oleh responden. Sehingga, dapat mempengaruhi pola konsumsi respoden terutama ketika berada di rumah.

Pada pola konsumsi, salah satu hal yang cukup mempengaruhi adalah pendapatan. Makanan yang disajikan dirumah dipengaruhi oleh tingkat pendapatan, dan makanan yang disajikan ini sangat mempengaruhi tingkat konsumsi dari remaja putri. Pendapatan dari hasil pekerjaan ini juga akan mempengaruhi keberagaman jenis makanan yang dikonsumsi ${ }^{15}$. Pendapatan yang didapat akan digunakan untuk membeli makanan sehingga daya beli akan dipengaruhi oleh pendapatan keluarga tersebut ${ }^{16}$.

Pada penelitian ini, semua responden diambil dari siswi kelas X SMAN 4 Surabaya. Berdasarkan hasil penelitian diketahui bahwa responden berusia 15-16 tahun dan sebagian besar responden berusia 16 tahun, dari kelompok kasus sebanyak $12(54,5 \%)$ orang, dan kelompok kontrol sebanyak $13(59,1 \%)$ orang. Jika dibandingkan dengan laki-laki, remaja putri lebih rentan terkena anemia terutama pada usia 10-19 tahun ${ }^{17}$.

Hasil penelitian menunjukkan bahwa sebagian besar respoden dari yang anemia maupun tidak anemia memiliki tingkat pengetahuan sedang, yaitu sebanyak 18 $(81,9 \%)$ orang pada kelompok anemia dan 19 (86,5\%) orang pada kelompok yang tidak anemia. Pengetahuan tentang gizi yang baik sangat dibutuhkan, hal ini dikarenakan pengetahuan akan mempengaruhi konsumsi terkait gizi seimbang.

Gizi seimbang sendiri merupakan makanan yang dikonsumsi sehari-hari dengan berbagai macam jenis dan jumlah makanan dan mengandung berbagai macam zat gizi yang dibutuhkan oleh tubuh ${ }^{18}$. Akan tetapi, semakin rendah tingkat pengetahuan remaja tentang 
Tabel 1. Tabel Distribusi Karakteristik dan Orang Tua Remaja Putri Kelas X di SMAN 4 Surabaya tahun 2019

\begin{tabular}{|c|c|c|c|c|}
\hline \multirow{2}{*}{$\begin{array}{l}\text { Karakteristik responden dan orang tua } \\
\text { responden }\end{array}$} & \multicolumn{2}{|c|}{ Anemia } & \multicolumn{2}{|c|}{ Tidak anemia } \\
\hline & $\mathrm{n}$ & $\%$ & $n$ & $\%$ \\
\hline \multicolumn{5}{|l|}{ Pekerjaan Ayah } \\
\hline PNS & 4 & $18,2 \%$ & 3 & $13,7 \%$ \\
\hline TNI/Polri & 0 & $0 \%$ & 3 & $13,7 \%$ \\
\hline Pegawai Swasta & 12 & $54,6 \%$ & 9 & $40,9 \%$ \\
\hline Pedagang/Wiraswasta & 5 & $22,7 \%$ & 5 & $22,7 \%$ \\
\hline Sudah meninggal & 1 & $4,5 \%$ & 2 & $9 \%$ \\
\hline \multicolumn{5}{|l|}{ Pekerjaan Ibu } \\
\hline PNS & 3 & $13,6 \%$ & 5 & $22,7 \%$ \\
\hline Pegawai Swasta & 5 & $22,7 \%$ & 0 & $0 \%$ \\
\hline Pedagang/Wiraswasta & 4 & $18,2 \%$ & 2 & $9,1 \%$ \\
\hline IRT & 10 & $45,5 \%$ & 14 & $63,6 \%$ \\
\hline Sudah meninggal & 0 & $0 \%$ & 1 & $4,6 \%$ \\
\hline \multicolumn{5}{|l|}{ Pendapatan Orang Tua } \\
\hline $1.5000 .000-9.000 .000$ & 17 & $77,3 \%$ & 18 & $82 \%$ \\
\hline$>9.000 .000-17.000 .000$ & 4 & $18,2 \%$ & 2 & $9 \%$ \\
\hline$>17.000 .000-25.000 .000$ & 1 & $4,5 \%$ & 2 & $9 \%$ \\
\hline \multicolumn{5}{|l|}{ Usia Responden } \\
\hline 15 tahun & 10 & $45.4 \%$ & 9 & $40.9 \%$ \\
\hline 16 tahun & 12 & $54.5 \%$ & 13 & $59.1 \%$ \\
\hline \multicolumn{5}{|l|}{ Pengetahuan } \\
\hline Tinggi & 3 & $13,6 \%$ & 1 & $4,5 \%$ \\
\hline Sedang & 18 & $81,9 \%$ & 19 & $86,5 \%$ \\
\hline Rendah & 1 & $4,5 \%$ & 2 & $9 \%$ \\
\hline
\end{tabular}

Tabel 2. Tabel Hubungan Antara Tingkat Konsumsi dengan kejadian Anemia pada remaja putri kelas X di SMAN 4 Surabaya tahun 2019.

\begin{tabular}{|c|c|c|c|c|c|c|}
\hline \multirow{2}{*}{ Tingkat Konsumsi Zat Gizi } & \multicolumn{2}{|c|}{ Anemia } & \multicolumn{2}{|c|}{ Tidak anemia } & \multirow{2}{*}{ P value } & \multirow{2}{*}{ OR } \\
\hline & $n$ & $\%$ & $\mathbf{n}$ & $\%$ & & \\
\hline \multicolumn{7}{|l|}{ Tingkat Konsumsi Protein } \\
\hline Kurang & 13 & $59,1 \%$ & 1 & $4,5 \%$ & $<0,001$ & 30,3 \\
\hline Cukup & 9 & $40,9 \%$ & 21 & $95,5 \%$ & & \\
\hline \multicolumn{7}{|l|}{ Tingkat Konsumsi Vitamin C } \\
\hline Kurang & 19 & $86,3 \%$ & 19 & $86,3 \%$ & 1,0 & 1 \\
\hline Cukup & 3 & $13,7 \%$ & 3 & $13,7 \%$ & & \\
\hline \multicolumn{7}{|l|}{ Tingkat Konsumsi Zat Besi } \\
\hline Kurang & 22 & $100 \%$ & 13 & $59,1 \%$ & $<0,001$ & 8,737 \\
\hline Cukup & 0 & $0 \%$ & 9 & $40,9 \%$ & & \\
\hline \multicolumn{7}{|l|}{ Tingkat Konsumsi Asam Folat } \\
\hline Kurang & 16 & $72,7 \%$ & 5 & $22,7 \%$ & 0,01 & 9,067 \\
\hline Cukup & 6 & $27,3 \%$ & 17 & $77,3 \%$ & & \\
\hline
\end{tabular}

*P- value didapatkan dengan uji korelasi pearson 
Tabel 3. Tabel rata-rata asupan zat gizi/hari pada kelompok kasus dan kelompok kontrol.

\begin{tabular}{lccc}
\hline \multicolumn{1}{c}{ Zat Gizi } & Anemia & Tidak Anemia & P value \\
\hline Protein & $44,17 \pm 13,12 \mathrm{~g}$ & $68,75 \pm 15,92 \mathrm{~g}$ & 0,004 \\
Vitamin C & $22,06 \pm 31,3 \mathrm{mg}$ & $33,81 \pm 33,9 \mathrm{mg}$ & 0,707 \\
Zat Besi & $4,8 \pm 2,1 \mathrm{mg}$ & $14,83 \pm 11,02 \mathrm{mg}$ & 0,01 \\
Asam Folat & $0,73 \pm 0,33 \mathrm{mg}$ & $1,63 \pm 1,03 \mathrm{mg}$ & 0,038 \\
\hline
\end{tabular}

anemia tidak menutup kemungkinan untuk tidak menderita anemia, apabila pola makan dan penyerapan zat besi remaja baik serta rutin meminum tablet besi ${ }^{19}$. engan kata lain, jika pengetahuan remaja terkait pola makan dan anemia tinggi, akan tetapi tidak ada perubahan perilaku dalam kehidupan sehari-hari maka tidak menutup kemungkinan untuk menderita anemia. Hal ini dibuktikan dalam penelitian yang dilakukan di SMAN 1 Tinambung yang menunjukkan bahwa tidak terdapat hubungan antara kejadian anemia dan pengetahuan pada remaja putri $(p=0,258)$, dalam penelitian tersebut disebutkan bahwa sebanyak $66 \%$ remaja memiliki pengetahuan yang cukup baik, namun sebanyak $74,8 \%$ remaja lebih memilih untuk mengkonsumsi makanan siap saji dibandingkan dengan makanan yang mengandung sayuran dan buahbuahan 20

Dari tabel 2 dapat diketahui bahwa terdapat hubungan yang signifikan antara tingkat konsumsi protein dengan kejadian anemia dengan kekuatan hubungan yang kuat dan berpola positif $(r=0,586)$, hasil $p$ value sebesar $<0,001$ dengan hasil $O R=30,333$ $(\mathrm{Cl}=3,433-267,988)$. Hasil OR tersebut menunjukkan bahwa remaja putri dengan tingkat konsumsi protein kurang beresiko 30, 333 kali lebih besar terkena anemia dibandingkan dengan remaja putri yang memiliki tingkat konsumsi cukup, sedangkan hubungan yang berpola positif tersebut menandakan bahwa jika asupan protein semakin tinggi maka kadar hb juga semakin tinggi.

Berdasarkan tabel 3, dapat diketahui bahwa rata-rata asupan responden yang tidak anemia lebih tinggi jika dibandingkan dengan kelompok yang anemia. Pada kelompok yang tidak anemia, rata-rata asupan protein yaitu sebesar 68,75 gram, sedangkan rata-rata asupan protein pada kelompok yang anemia yaitu sebesar 44,17 gram.

Salah satu zat gizi yang memiliki peran penting adalah protein. Protein bermanfaat sebagai zat pembangun dan pengatur, selain itu protein juga mengatur kesehatan manusia dengan menyediakan precursor molekul dari asam amino dan juga berfungsi sebagai komponen pada sel tubuh, protein juga memiliki peran dalam transportasi zat besi ke sum sum tulang belakang untuk pembentukan sel darah merah ${ }^{21}$. Asupan protein, terutama pada protein hewani membantu peningkatan penyerapan zat besi, maka dari itu rendahnya asupan protein dapat mempengaruhi kadar $\mathrm{Hb}$ menjadi kurang, sehingga dapat mengakibatkan anemia ${ }^{22}$. Protein juga membantu penyerapan vitamin $C$ untuk mendukung proses sintesis sel darah merah ${ }^{23}$. Dari hasil penelitian di SMAN 1 Gresik ini, juga terbukti bahwa terdapat hubungan yang signifikan antara asupan protein dengan kejadian anemia, dimana semakin rendah asupan protein pada remaja putri maka semakin rendah pula kadar hemoglobin remaja putri ${ }^{24}$. Hal tersebut juga sejalan dengan penelitian yang dilakukan oleh Pratiwi di MTS Ciwandan, pada penelitian tersebut didapatkan hubungan yang signifikan antara asupan protein dengan kejadian anemia dengan $p$ value $=0,000$ dan $\mathrm{OR}=5,687$, yang berarti terdapat hubungan yang sigifikan antara asupan protein dengan kejadian anemia dan responden yang memiliki asupan protein yang kurang beresiko 5,687 kali lebih besar jika dibandingkan dengan responden yang memiliki konsumsi protein yang cukup ${ }^{23}$.

Dari hasil penelitian ini dapat diketahui bahwa tidak terdapat hubungan yang signifikan antara tingkat konsumsi vitamin $C$ dengan kejadian anemia dengan hasil $p$ value sebesar $1,00(>0,05)$ dengan hasil $\mathrm{OR}=1$ $(\mathrm{Cl}=0,179-5,596)$. Besarnya asupan vitamin $\mathrm{C}$ pada remaja putri berhubungan dengan tingkat kecukupan vitamin $C$ dalam tubuh. Vitamin $C$ berfungsi untuk membantu penyerapan zat besi dalam pencegahan terjadinya anemia 25 .

Berdasarkan tabel 3, dapat diketahui bahwa rata-rata asupan vitamin c responden yang tidak anemia lebih tinggi jika dibandingkan dengan kelompok yang anemia. Pada kelompok yang tidak anemia, rata-rata asupan vitamin c yaitu sebesar $33,81 \mathrm{mg}$, sedangkan rata-rata asupan vitamin c pada kelompok yang anemia yaitu sebesar $22,06 \mathrm{mg}$.

Pada penelitian ini, tidak terdapat hubungan yang signifikan antara tingkat konsumsi vitamin C dengan kejadian anemia. Hal ini disebabkan banyaknya faktor lain yang dapat mempengaruhi kejadian anemia seperti riwayat cacingan dan kebiasaan dalam mengkonsumsi tablet tambah darah. Selain itu, penyebab lain tidak signifikannya asupan vitamin C dengan kejadian anemia bisa jadi disebabkan karena adanya penghambat penyerapan zat besi atau faktor inhibitor yang pada penelitian ini tidak disingkirkan, padahal hal ini dapat mempengaruhi kerja dari vitamin c. Beberapa contoh zat penghambat zat besi adalah asam fitat, asam oksalat, dan polifenol seperti $\operatorname{tanin}^{26}$. Hal ini sejalan dengan penelitian yang dilakukan di SMK Penerbangan Bina Dhirgantara Karangannya dengan nilai $p$ value sebesar 0,92 yang berarti tidak terdapat hubungan antara asupan vitamin C dengan kejadian anemia, vitamin $C$ sendiri berfungsi untuk membantu penyerapan zat besi untuk pencegahan anemia, namun jika zat besi yang dikonsumsi rendah maka penyerapan zat besi yang dibantu vitamin $\mathrm{C}$ tidak akan berjalan dengan baik ${ }^{22}$. 
Dari hasil penelitian diatas dapat diketahui bahwa terdapat hubungan yang signifikan dan bersifat positif antara tingkat konsumsi zat besi dengan kejadian anemia dengan kekuatan hubungan yang kuat dan berpola positif $(r=0,507)$, dan didapatkan hasil $p$ value $<0,001$ dengan $\mathrm{OR}=8,737(\mathrm{Cl}=3,309-29,560)$ Hasil OR tersebut menunjukkan bahwa remaja putri dengan tingkat konsumsi zat besi kurang beresiko 8,737 kali lebih besar terkena anemia dibandingkan dengan remaja putri yang memiliki tingkat konsumsi cukup, sedangkan hubungan yang bersifat positif tersebut menandakan bahwa jika asupan zat besi semakin tinggi maka kadar $\mathrm{Hb}$ juga semakin tinggi. Hal ini sejalan dengan penelitian yang dilakukan di MTS ciwandan, pada penelitian tersebut didapatkan hasil $p$ value 0,011 dan OR sebesar 5,906 23. Selain itu, berdasarkan penelitian yang dilakukan diwilayah kabupaten banyumas, diketahui bahwa remaja putri yang memiliki asupan zat besi kurang beresiko 33,5 kali lebih tinggi jika dibandingkan dengan remaja putri yang memiliki asupan cukup ${ }^{27}$.

Berdasarkan tabel 3, dapat diketahui bahwa rata-rata asupan responden yang tidak anemia lebih tinggi jika dibandingkan dengan kelompok yang anemia. Pada kelompok yang tidak anemia, rata-rata asupan zat besi yaitu sebesar $14,83 \mathrm{mg}$, sedangkan rata-rata asupan zat besi pada kelompok yang anemia yaitu sebesar 4,8 $\mathrm{mg}$.

Zat besi memiliki peran yang cukup penting dalam tubuh beberapa diantaranya adalah berperan dalam pembentukan hemoglobin, membantu proses metabolisme dengan membantu berbagai macam enzim dengan cara mengikat oksigen. Zat besi terdiri dari 2 macam, yaitu zat besi heme dan zat besi non heme. Zat besi heme yang berasal dari daging, hati, unggas dan ikan dapat diabsorbsi lebih banyak dibandingkan dengan zat besi nonheme, oleh sebab itu jika asupan zat besi kurang dan frekuensi konsumsi zat penghambat penyerapan lebih sering dibandingkan konsumsi sumber zat besi maka kemungkinan dapat menyebabkan kadar zat besi yang ada didalam tubuh rendah dan dapat memicu terjadinya anemia zat besi ${ }^{24}$.

Berdasarkan hasil analisis hubungan tingkat konsumsi asam folat dan anemia didapatkan hasil $p$ value $=0,01$ dan $\mathrm{OR}=9,067(\mathrm{Cl}=2,306-35,65)$, hal ini menunjukkan bahwa terdapat hubungan yang signifikan antara tingkat konsumsi asam folat dengan kejadian anemia dengan kekuatan hubungan yang kuat dan berpola positif ( $r=0,501)$, selain itu didapatkan hasil OR sebesar 9,067 yang menunjukkan bahwa remaja putri dengan tingkat konsumsi asam folat rendah 9, 067 kali lebih beresiko untuk terkena anemia dibandingkan dengan remaja putri dengan tingkat konsumsi asam folat yang cukup, sedangkan hubungan yang bersifat positif tersebut menandakan bahwa jika asupan asam folat semakin tinggi maka kadar hb juga semakin tinggi.

Berdasarkan tabel 3, dapat diketahui bahwa rata-rata asupan responden yang tidak anemia lebih tinggi jika dibandingkan dengan kelompok yang anemia. Pada kelompok yang tidak anemia, rata-rata asupan asam folat yaitu sebesar $1,63 \mathrm{mg}$, sedangkan rata-rata asupan asam folat pada kelompok yang anemia yaitu sebesar $0,73 \mathrm{mg}$.

Folat atau asam folat yang diperlukan dalam pembentukan globin dan dalam maturasi inti sel. Asam folat banyak terkandung dalam hati ayam maupun sapi dan juga sayuran berdaun hijau. Asam folat tidak dapat disimpan di tubuh dalam jumlah yang besar, maka dari itu untuk mencukupi kebutuhan remaja putri perlu didapatkan asupan yang cukup dari diet secara terusmenerus. Defisiensi asam folat ini dapat menyebabkan inti sel darah merah membesar. Hal tersebut disebabkan karena maturasi inti sel yang terhambat, akan tetapi proses pembentukan hemoglobin tetap berjalan secara normal sehingga hemoglobin tetap terbentuk akan tetapi dengan inti sel yang membesar (megalobast) ${ }^{28}$.

Penelitian ini memiliki kelebihan dan kekurangan. Kelebihan dari penelitian ini adalah skrining awal pegukuran kadar hemoglobin dilakukan langsung oleh tenaga ahli yaitu perawat sehingga dapat terjamin keamanannya, selain itu pada saat proses wawancara dilakukan dengan cara memanggil responden secara bergantian keruangan yang terpisah dengan ruang kelas sehingga lebih kondusif dan responden lebih fokus. Kekurangan dari penelitian ini adalah populasi tidak dapat mencakup kelas $\mathrm{X}$ hingga kelas XII dikarenakan perizinan dari pihak sekolah dan juga biaya yang tidak mencukupi.

\section{KESIMPULAN}

Dari hasil penelitian dapat diketahui bahwa ratarata asupan per hari dari zat gizi protein, vitamin c, zat besi dan asam folat lebih tinggi pada kelompok yang tidak anemia dibandingkan dengan kelompok yang tidak anemia. Remaja putri yang memiliki tingkat asupan protein yang kurang memiliki resiko 30,33 kali lebih besar terkena anemia dibanding mereka yang memiliki tingkat asupan protein yang cuku[. Begitu juga pada mereka dengan tingkat konsumsi zat besi dan asam folat yang kurang memiliki resiko anemia 8-9 kali lipat lebih tinggi.

\section{ACKNOWLEDGEMENT}

Ucapan terima kasih diberikan kepada kepala humas SMAN 4 Surabaya, karena telah mengizinkan peneliti untuk melakukan pengambilan data di SMAN 4 Surabaya, selain itu peneliti juga mengucapkan terima kasih kepada siswi kelas $\mathrm{X}$ di SMAN 4 Surabaya yang telah bersedia menjadi responden. Tak lupa, ucapan terima kasih juga peneliti sampaikan kepada salah satu guru TU di SMAN 4 Surabaya, yaitu Bu Eni yang banyak membantu dalam proses pengambilan data untuk penelitian ini.

\section{REFERENS}

1. Alwi, I Sudoyo, Aru W, Setiyohadi, Bambang, M Simadibrata, S. S. Buku Ajar Ilmu Penyakit dalam jilid II. (EGC, 2014).

2. WHO. Micronutrient Deficiencie : Iron Deficiency

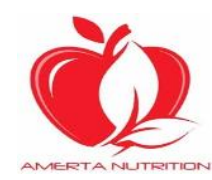

(C)2019. Sholihah, dkk. Open access under CC BY - SA license.

Received: 28-05-2019, Accepted: 10-07-2019, Published online: 09-9-2019. doi: 10.20473/amnt.v3.i3.2019.135-141, Joinly Published by IAGIKMI \& Universitas Airlangga 
Anemia. (2015). Available at: http://www.who.int/nutrition/topics/en/. (Accessed: 26th January 2019)

3. Badan Penelitian dan Pengembangan Kesehatan Depkes RI. Hasil Utama Riset Dasar (Riskesdas) 2018. (2018). Available at: http://www.depkes.go.id/resources/download/i nfo-terkini/hasil-riskesdas-2018.pdf. (Accessed: 26th January 2019)

4. Sya'bani, N. \& Sumarmi, S. Hubungan Status Gizi Dengan Kejadian Anemia Pada Santriwati Di Pondok Pesantrendarul Ulum Peterongan Jombang. J. Keperawatan Muhammadiyah 1, 715 (2016).

5. Masthalina, H. ., Yuli, D. \& Yuliana. Pola Konsumsi (Faktor Inhibitor dan Enhancer Fe) terhadap Status Anemia Remaja Putri. J. Kesehat. Masy. 11, 80-86 (2015).

6. Masrizal. Anemia Defisiensi Zat Besi. J. Kesehat. Masy. 2, 140-145 (2017).

7. Melina, P. . Hubungan Pola Konsumsi dan Kebiasaan Konsumsi TTD dengan Kejadian Anemia Pada Remaja Putri di SMKN 1 Manggis, Kabupaten Karangasem. (Poltekkes Denpasar, 2018).

8. Wahyu, M. P. Hubungan antara Status Gizi, Siklus dan Lama Menstruasi dengan Kejadian Anemia Remaja Putri di SMA Negeri 3 Surabaya. (Universitas Airlangga, 2016).

9. Rabbani, F. Hubungan Citra Tubuh dan Status Gizi dengan Status Anemia pada Remaja Putri di SMPN 55 Surabaya. (Universitas Airlangga, 2018).

10. Jasmani. Faktor yang Berhubungan dengan Anemia Pada Remaja Putri. Skripsi (2010).

11. Kuntoro. Metode Sampling dan Penentuan Besar Sampel. Edisi Revisi. (Pustaka Melati, 2010).

12. Baliawati, Y. ., Khomsan, A. \& Meti, D. Pengantar Pangan dan Gizi. (Penerbit Swadaya, 2011).

13. Gibson, R. . Principles of Nutritional Assessment. (Oxford University Press, 2005).

14. (WNPG), W. N. P. G. No Title. (Lembaga IImu Pengetahuan Indonesia, 2004).

15. Notoadmodjo. Promosi Kesehatan dan Perilaku Kesehatan. (Rineka Cipta, 2012).

16. Barasi, M. At Glance: Ilmu Gizi. (Erlangga, 2009).
17. Fajriyah, Nuniek, N., Laelatul \& Huda, F. Gambaran Tingkat Pengetahuan Tentang Anemia Pada Remaja Putri. J. Ilmu Kesehat. 9, 1-6 (2016).

18. Marmi. Gizi Dalam Kesehatan Reproduksi. (Pustaka Pelajar, 2014).

19. Amany, H. . Hubungan Tingkat Pengetahuan Tentang Anemia. Dengan Kejadian Anemia Pada Siswi Di 3 SMA Kota Yogyakarta 2015. Skripsi (2015).

20. Hapzah \& Ramlah, Y. Hubungan tingkat pengethuan dan status gizi terhadap kejadian anemia remaja putri pada siswi kelas III di SMAN 1 Tinambung Kabupaten Polewali Mandar. J. Media Gizi Pangan 8, 1-15 (2012).

21. Gallagher, M. The Nutrients and Their Metabolism. In: Mahanan LK, Escott-Stump S. Krause Food, Nutrition, and Diet Therapy. (Saunders, 2008).

22. Denistikasari, R. HUBUNGAN ANTARA ASUPAN PROTEIN, ZAT BESI (Fe) DAN VITAMIN C DENGAN KEJADIAN ANEMIA PADA SISWI SMK PENERBANGAN BINA DHIRGANTARA KARANGANYAR. (Universitas Muhammadiyah Surakarta, 2016).

23. Pratiwi, E. Faktor-faktor yang Mempengaruhi Anemia pada Siswi MTS Ciwandan. (Universitas Islam Negeri Syarif Hidayatullah, 2016).

24. Sholicha, C. Hubungan Asupan Fe, Protein, Vitamin C dan Pola Menstruasi dengan Kejadian Anemia Pada Remaja Putri. (Universitas Airlangga, 2018).

25. Setijowati, N. Hubungan Antara Asupan Zat Gizi Mikro Seng (Zinc) Dengan Dismenorea Primer Pada Remaja Putri di MAN Kota Blitar. (Universitas Brawijaya, 2012).

26. Nurdiansyah, F. Hubungan Antara Asupan Vitamin C, Indeks Massa Tubuh dan Kejadian Anemia pada mahasiswi PSPD UIN Syarif Hidayatullah. (UIN Syarif Hidayatullah Jakarta, 2012).

27. Sari, H. P., Dardjito, E. \& Anandari, D. Anemia Gizi Besi Pada Remaja Putri di Wilayah Kabupaten Banyumas. Kesmas Indones. 8, 16-31 (2016).

28. Proverawati, A. Anemia dan Anemia dalam Kehamilan. (Nuha Medika, 2011). 